\title{
THE MISSION OF THE CHURCH IN THE WEST
}

\author{
Capodistrias Hämmerli*
}

\begin{abstract}
Since a hundred of years, a large number of Orthodox Christians have emigrated to Western Europe and North America. This essay tries to explores the main features of the religious and cultural context which they have emigrated to and the main difficulties they face being a minority religious group in a culture that is post-Christian, after God, and unable to understand the fundamentally transcendent nature of the experience sought after by Orthodox believers. This essay argues that rediscovering the apostolic spirit of ancient Western Christian Saints is the only way to escape the trap of secular relativism and ethnocentrism that both betrays the universal truth of Orthodox Christianity.
\end{abstract}

Keywords: mission, Orthodox Diaspora, Western Christianity, pluralism, secularism.

\section{The Collapse of Western Christianity}

Herman Tristram Engelhardt, in his forthcoming monograph called "After God"1, argues that an unparalleled cultural event occurred over the last half-century in the West: the demographical and cultural collapse of Roman Catholicism. "When Pope John XXIII opened the Second Vatican Council in 1962, the Catholic

\footnotetext{
* Rev., PhD Candidate, Department of Theology, University of Fribourg, Switzerland.

${ }^{1}$ The book is expected to be published in English during summer 2015. An Italian translation of a slightly shorter version of the same monograph has already been published, with the title Dopo Dio.
} 
Church in America was in the midst of an unprecedented period of growth. Bishops were ordaining record numbers of priests and building scores of seminaries to handle the surge of vocations. Young women by the thousands gave up lives of comfort for the austerity of the convent ${ }^{2}$." When Jones published this study about Roman Catholicism in the USA in 2003, the crisis of the Roman Catholic Church, in America and in the entire Western world had already become dramatic. "Beyond a vague understanding of a 'vocation crisis,' both the faithful and the general public have no idea how bad things have been since the close of the Second Vatican Council in $1965^{3}$." The demographical and statistical study of Jones demonstrates how much was lost in the last decades. This historically unprecedented decline of Roman Catholicism in Western Europe, North and South America, and Australia was paralleled with a complete reshaping of the religious landscape and the rise of the secular, pluralist, and postmodern culture we know today.

In his analysis of the causes of the dramatic waning of Roman Catholicism, Engelhardt highlights three main causes.

First (1), the progressive loss of religious rituals in the daily life of believers: the quasi complete abandon of the practice of fast, the weakening of the habit to say grace before meals, and the lost of the religious rhythms related to the liturgical calendar. The religious habits and rhythms which once constituted the core of Western Christian culture have been replaced by habits and rhythms that no longer recall the importance of Christ. The transcendence has been banned form daily life at the culturally decisive level of shared social habits that were the basis for a strong Christian religious identity. With the disappearance of those habits is also gone the shared social feeling of the importance of God in human life.

\footnotetext{
${ }^{2}$ See Kenneth C. Jones, Index of Leading Catholic Indicators, Roman Catholic Book, Fort Collins, 2003, p. 7.

3 Jones, op. cit., p. 8. The example of seminarians in the USA is telling: Between 1965 and 2002, the number of seminarians dropped from 49000 to 4700. In 1965, 104000 nuns were teaching in the USA, whether in 2002 they were only 8200 .
} 
Second (2), the profound sense that the holiness of the living God is serious, that the true God is He Who revealed Himself in His Son Jesus Christ and sent His Most Holy Spirit at the Pentecost to found the Church was supplanted by Pluralism, a philosophical doctrine that holds that all religious truths are equal (in their political and cultural insignificance). The Trinitarian God in the Name of Whom Jesus sent His Apostles to baptize all nations (Matthew 28:19-20) in order to gather the whole world in a unique community of right worship and right belief, which is authentic orthodoxy, has become one possible belief among many in Western contemporary culture (Taylor $\left.{ }^{4}\right)$.

Third (3), the all-encompassing and limitless demands of a true Christian life completely dedicated to God have been recast as an optional, private matter, a spiritual activity that may be deemed useful if it "helps" somebody to better manage and cope with the difficulties of his earthly life and helps him accomplish more successfully his own goals. Spirituality has become a tool, a means to reach a more self-satisfying life that belongs wholly to the immanent.

According to Engelhardt, the Second Vatican Council, by trying to adapt Christianity to the contemporary secular culture, created a "toned-down God" that is not worth living or dying for. The force and pregnancy Roman Catholic culture had exercised on so many during centuries was not any more possible, once the Roman Catholic Church herself accepted to enter a logic of compromise with the world and its rising secular culture. Having weakened (and sometimes renounced) to the centrality of religious truth and its exclusive character, Western Christianity lost its ability to be taken seriously by most people and by Western culture at large. Who would still be willing to die for what has become "one opinion among many other valid opinions"?

After God, we find ourselves in a world of competing narratives and ethnocentrisms which all fail to have an anchor in the

\footnotetext{
${ }^{4}$ The fact that Christian belief has become one option among many is the main argument of Charles Taylor's A Secular Age.
} 
eternal reality. Everything floats freely in the flat horizon of the immanent and each moral narrative is part of an endless (MacIntyre ${ }^{5}$ ) debate and an ever-negotiable consensus that by definition cannot reach stability. Everything changes. Change has become the only stable component of contemporary culture.

I have focused those introductory words on the last fifty years because they best define the situation which the Orthodox have migrated into when coming to Western Europe and North America. However, it should be noted that the process of secularization and spiritual departure from authentic Christianity began much earlier in the West. As Yves Congar himself recognizes ${ }^{6}$, the nature of Christian spirituality changed radically in Western Europe in the centuries following the rupture with Orthodox Christianity. Later, the philosophy of "Enlightenment," endorsed by the French Revolution and spread in Europe by Napoleon's bayonets accomplished a profound break in the continuity of Western Christian culture. However, it is later that a thoroughly secularized culture emerged. Engelhardt recalls that if Hegel (1770-1831) started to speak about the "death of God" in Glauben und Wissen, trying to cut the anchor of Western culture in the transcendent God, if Nietzsche (1844-1900) could already recognize that the "death of God" had already happened in his time, it is only during the second half of the $20^{\text {th }}$ century that the Roman Catholic Church, the bulwark and stronghold of medieval Western Christian culture, accepted that secular and immanent principles would reshape its own doctrine and religious practice. As soon as the wolf had been let within the sheepfold, the flock became rapidly much thinner as the eloquent figures of Jones show. Once doctrine and morality are cut from their eternal foundation, they float along, being dragged by contemporary culture, without much resistance.

${ }^{5}$ See the argument of Alasdair MacIntyre in his famous book After Virtue, University of Notre Dame, Notre Dame (Indiana), 2007 ( $3^{\text {rd }} \mathrm{ed}$.).

${ }^{6}$ See Yves Congar, Neuf cents ans après. Notes sur le 'Schisme oriental', Éditions Chevetogne, Paris, 1954. 


\section{The rise of a secular culture}

The Sixties led to a profound rewriting of the principles that define today's European project of unity. God, the immortality of the human soul, and therefore the eternal significance of our acts had been the underpinning thought categories of religious European culture for centuries. The loss of the transcendent gave rise to a new culture that values life in this world as the ultimate good. Comfort, pleasure, and security became the arch-principles of a society whose entire energy is bent on earthly matters. Since its endeavors and goals belong exclusively to $c u$ siècle (this world), we call it a secular culture ${ }^{7}$.

Secular culture sets a new hierarchy of values, where the good life in this world is tantamount: peace, prosperity, and the feeling of happiness are perceived and acclaimed as the most important standards. For this reason, they are nowadays endorsed by the European Union as the core political objectives of its project of a unified Europe. In this context, matters like eternal life, the importance of religious doctrines, and right worship can only be accepted so long as they do not disrupt the dominant secular political and legal framework developed by the European Commission and by European justice courts.

In order to be acceptable, religious doctrines and rituals have to conform and adapt themselves to this new cultural context. This usually means accepting to "translate" religious convictions in a common secular "language" that is understandable in terms of the dominant secular ethos. This translation is presented by the European Union as a reasonable price that religious communities have to pay in order for our plural society to achieve the greater goods of peace and security.

The contemporary European man is one who knows - thanks to the secular history classes he attended - that religious truth is a dangerous matter that can threaten the stability of an entire society.

${ }^{7}$ The French word siècle (which can mean "this world") is the root of the word séculier, which became secular in English. 
The record of religious wars in Western Europe is accepted as a sufficient "proof" that religious doctrines are dangerous when people take them seriously.

During centuries, the Papacy and the "Holy Germanic Roman Empire" of the Franks were struggling against each other to impose their own model of unity in Western Europe. The Protestant Reformation further broke the unity of Western Europe, creating a context that led to several religious wars that have deeply marked the European conscience. The principle of tolerance slowly emerged as a confessionally neutral third-ground that could give a new foundation for politics. Philosophically, this move toward a political solution that would avoid conflicts between confessional states by deconfessionlizing them is one of the strongest root of contemporary secularism.

With the decline of Christianity in Western Europe during the second half of the $20^{\text {th }}$ century, the principle of tolerance underwent further transformations until it became a new political doctrine which prescribes religious relativism as a means to preserve social peace by achieving a confessionally neutral state. The initial principle of tolerating the wrong opinions of others went through a substantial reinterpretation: to be tolerant today means to respect the opinions of others, even if theirs differ with mine. In other words, doctrinal disagreement and religious differences came to be acclaimed as something good in itself, indeed, as a "vital asset of democracy."

This new interpretation of the principle of tolerance radically deflates the importance of religious truth and requires all to accept to "translate" their religious creeds and customs into the unpolemical language of "tolerance, respect, and dialogue." Since this new political principle prescribes that no doctrine can be held as true outside the politically and legally insignificant "private sphere," while at the same time it celebrates diversity of opinion as a positive asset for democracy, we call it prescriptive pluralism.

Prescriptive pluralism lays down the framework within which one is allowed to argue in courts, make political arguments in the public forum, or require his religious peculiarities to be taken into 
account. Prescriptive pluralism presents itself as a post-metaphysical and post-religious ethos that is religiously neutral. In one word, a fully postmodern ethos that does not recognize any anchor in the transcendent. On the one hand, prescriptive pluralism is generous with anybody willing to stop taking truth seriously. On the other hand, it treats those who hold fast to the exclusive character of their religious beliefs as dangerous outsiders. In one word, it makes religious relativism compulsory for all those want to play an active role in the life of the new secular world.

\section{Orthodox Migrants in the West}

In parallel with the collapse of Western Christianity and the rise of a secular culture in the West, an important event for the history of Christianity happened: Orthodox Christians came in the West in significant numbers through several migrations waves coming from Eastern Europe. This event passed mainly unnoticed, however, it is a major change for Orthodoxy and its presence in the world.

Maria Hämmerli synthetizes the scheme of Orthodox migration in Western Europe:

There are two key events that produced a significant exodus of the Orthodox populations to the West: the advent and the fall of communism in Eastern Europe. 1917 and 1990 were turning points for the European religious landscape: while the former brought into power a political regime that was highly hostile to religion and imposed radical secularization in Eastern Europe, the latter marked the reinstatement of religious freedom and an unprecedented comeback of religion in those societies. While 1917 was the beginning of several waves of political migration, 1990 led to a diversification of migration causes, though economic precariousness in the sending countries remains a key issue. Other events that are at the origin of Orthodox presence in the West are military conflicts in the Mediterranean (for instance the 1919-1922 Greek-Turkish war) and in the former Yugoslavia (end of the 1990s) ${ }^{8}$.

${ }^{8}$ Maria Hämmerli, "Introduction" (pp. 1-26) in Orthodox Identities in Western Europe. Migration, Settlement and Innovation, Ed. Maria Hämmerli and Jean- 
An important event for the identity and self-understanding of the Orthodox in Western Europe is the coming of an elite emigration (political, intellectual, and military dissidents) caused by the Bolshevik Revolution (1917). The Institut de théologie orthodoxe Saint-Serge in Paris and, later, the St. Vladimir's Orthodox Theological Seminary in New York played an important role to give Orthodoxy a public voice in the West. Not only did these two intellectual centers do a work of translation into Western languages (French and English especially) of key texts of the Orthodox Tradition, but also several leading theologians wrote directly in Western languages to explain, in a way comprehensible to the local culture, the content, differences, and specificities of the Orthodox Christian Faith. Some of the most important were Father Georges Florovksy ${ }^{9}$, Vladimir Lossky ${ }^{10}$, Paul Evdokimov ${ }^{11}$, Father Alexander Schmemann and John Meyendorff ${ }^{12}$.

M. Hämmerli reflects on the situation of the Orthodox in the West and describes their situation as a minority status, which contrasts sharply with the context they emigrated from, where Orthodoxy dominates the cultural fabric of the society. She identifies five key differences that characterize the experience of Orthodox living in the West ${ }^{13}$.

First (1), for Eastern Orthodox migration means deterritorialization from a social, cultural, and political context which

François Mayer, Ashgate, Surrey (England) and Burlington (USA), 2014, p. 6.

${ }^{9}$ He played a major role in the "return to the Church Fathers" that happened at the beginning of the $20^{\text {th }}$ century and that led to a profund renewal of Orthodox theological thinking.

${ }^{10}$ In particular his very influencial book, La théologie mystique de l'Église d'Orient, Éditions Montaignes, 1944. An English translation was published in 1997, with the title The Mystical Theology of the Eastern Church.

${ }^{11}$ His major book is L'orthodoxie, Desclée De Brouwer, 1979, which presents Orthodoxy to a French audience.

${ }^{12}$ He played an important role in translating (especially Saint John Palamas) and making hesychasm known in the Western world.

${ }^{13}$ See M. Hämmerli, op. cit., pp. 9-13. 
backs their religious identity. In the new context, Orthodoxy takes new meanings: being faced with contestation of the content of their faith, the Orthodox develop more theological literacy in order to know who they are and respond to their critics. Orthodox Faith, which is taken for granted and self-evident in their home countries, becomes a peculiarity that needs to be rationalized, understood, and re-appropriated in a different way.

Second (2), being a minority in the West, the Orthodox live outside of an Orthodox society and culture, which means that they live outside the Orthodox habitus structured by the yearly rhythms of the liturgical calendar, which defines fasting and feasting periods for the whole society. In traditional Orthodox countries a whole set of habits mark the preparation of the great feasts of Pascha (Easter) and Christmas. For example, families clean their house, prepare nice clothing for the feast, cook special food in advance, cease or slow down their professional activity before and during Holy Week, etc. Since the whole society enters within this "pre-feast" mode, it is easy to attend special religious services during weekdays before the feast without creating a situation of conflict or tension with one own's professional obligations. The situation is totally different for Orthodox who have a job in Western Europe, where the date of Orthodox Easter is usually different from its Western counterpart and the professional rhythm continues its course almost without change. It is difficult to keep those religious habits in a context where the rhythms are defined almost exclusively according to secular and professional standards. However, as Engelhardt argues, it is exactly there, at the level of rituals and religious habits that lies what is most essential in order to preserve one's own religious identity.

Third (3), M. Hämmerli insists on the situation of the clergy in Western Europe. Priests have no salaries from the state (being a nontraditional minority religion from the point of view of the host Western countries). Most of them have a daily job during weekdays, wearing civil clothing, and in fact having two different lives in two different contexts. Their authority and special status as priests, which is recognized as such by everybody in Orthodox countries, shrinks 
down to the sphere of their parish in the West. Being an Orthodox priest in Western Europe (with some exceptions) is much less attractive than in the host countries at the financial and social level. The positive aspect of this situation is that Orthodox clergy in the West has a much higher proportion of truly dedicated and sincere priests.

Fourth (4), the legal situation of Orthodox parishes in the West is very different from their situation in Orthodox countries. Usually they are not recognized as religious organizations (this varies from country to country) but rather as non-profit associations or entities in the context of a legislation that was not conceived for an Orthodox type of institution. A key issue that M. Hämmerli has observed in her fieldwork is that the legal organization the Orthodox parishes have to conform to, in terms of the juridical status, bring a democratic element at the heart of their life. In most countries, the law establishes that an association must have a General Assembly that has ultimate authority in the association and which has to function, as least theoretically, according to a democratic model where the majority can force a decision upon the minority. This conflates deeply with the Orthodox way of handling things in parish life, which is based on a consensus expressed and also initiated by the figure of the priest. Often, part of the traditional authority of the priest is transferred to a committee whose decision taking procedure often leans towards democratic standards alien to the way parishes function in traditionally Orthodox countries. This committee, usually composed by a majority of lay Orthodox people, has an authority that goes beyond financial matters and may also decides on matters as the choice of the church building, the organization of parish life, etc. This sometimes participates in undermining the role of the priest as a Father for his flock.

Five (5), M. Hämmerli argues that the key-phrase "Orthodox Diaspora," often used to describe the Orthodox coming from Eastern Europe and living in Western Europe or the Americas, is inadequate as a descriptive sociological category. We can speak of a "Romanian Orthodox Diaspora" or a "Greek Orthodox Diaspora," she argues, 
since they have ties with their respective Mother Churches that are abroad. For those Orthodox migrants, the concept of diaspora, of being away from their religious center of authority corresponds, at least partially, to a reality. However, the ethnic element is dominant in what makes them being away from their center, which is core to the definition of the concept of diaspora. They are away from their land, language, and culture that has been molded by Orthodox Christianity. M. Hämmerli argues convincingly that the sum of ethnic Orthodox diasporas does not make a unique "Orthodox Diaspora," since it is the individual ethnic element that makes each of them a "diaspora" and not so much the religious element, which would be a ground to speak about a single Orthodox Diaspora ${ }^{14}$.

\section{The Orthodox Roots of the West}

In the $4^{\text {th }}$ and $5^{\text {th }}$ centuries, a great part of what has now become Western Europe was part of the Christian Roman Empire $\left(4^{\text {th }}\right.$ $-15^{\text {th }}$ centuries) founded by Emperor Saint Constantine the Great (272-337) and Emperor Saint Theodosius the Great (347-395). The conversion of the Roman Empire opened the way for the implantation of Christianity in todays Italy and France, the Iberic Penninsula and many more territories that were lost to Muslim conquerors since the $6^{\text {th }}$ century. Several Barbarian peoples adopted the Christian religion because of the influence of the Romans ${ }^{15}$. An army of apostles and bishops preached, explained, and transmitted the Holy Tradition, baptizing and celebrating the Holy Mysteries of the Church, laying the foundation for the ancient Western Christian culture. The early history of the West, from St. Ireneus of Lyon $(+202)$, a great Father of the Church, disciple of St. Polycarp of Smyrna (who had been the disciple of St. John the Evangelist), to the

${ }^{14}$ See M. Hämmerli, op. cit., pp. 14-15.

${ }^{15}$ One could think, for example, of the baptism of Clovis and the influence of his wife the Queen Saint Clothilde. The example of the Burgundy, who converted to Christ, "the God of the Romans, because He often gave them military victory" as a last resort as they were afraid to be destroyed by Attila the Hun and his hosts, is also very interesting. 
conversion King Olaf, who became the Enlightener of Norway and a martyr in 1030, the series of great saints who brought the Gospel in the West is amazing. Let us recall at least some of them: St. Martin of Tours (+397), in France, a bishop whose vita was a medieval "bestseller"; St. Gregory of Tours (+429), Bishop and Hagiographer; St. John Cassian $(+435)$ the Roman, who imported into the West the Orthodox monastic tradition from its birthplace in Egypt; St. Severnius (+482), Apostle of Austria; St. Gall of Ireland, Apostle of Switzerland (+646); St. Boniface of Fulda $(+754)$, Apostle to the Germans; St. Ansgar (+865), Bishop of Hamburg and Bremen, Christianizer of Scandinavia and Apostle of Denmark; and so many more.

The conception that "the West was in communion with the Orthodox Church during the first millenium" is misleading. The West was the Church as well as the East was the Church. The Patriarchate of Rome defended and kept the right faith in many occasions when the Patriarchate of Constantinople fell into heresy. The early Christian history of the West is part of Orthodox Christian history. The early Christian history of the West is a missionary history that tells how the Pagan West became Christian. Only in the last fifty years did the West complete its long return to a thoroughly non-Christian culture. If Orthodox migrating today to the West constitute a religious minority, away from the Orthodox habitus and culture from their homelands, it is because Orthodoxy became extinct in the West. The roots of the West are Orthodox.

\section{5. "Orthodox Diaspora": a Misleading Concept}

Maria Hämmerli argues that the idea that the Orthodox in the West form a diaspora is not only inaccurate as a descriptive sociological concept, but that this concept is even more misleading at the theological level ${ }^{16}$. The Jewish concept of diaspora, based on a situation away from the Temple of Jerusalem and away from Holy Land which are both geographically static centers cannot apply to

${ }^{16}$ See Maria Hämmerli, op. cit., pp. 16-17. 
Orthodox ecclesiology because Orthodox ecclesiology is based on the concept of local churches, which allows for a plurality of locations, each local church epitomizing and indeed being the one, holy, apostolic and Catholic Church through the celebration of the Eucharist. Hence, diaspora is not a Christian ecclesiological category.

Foundational for the Orthodox ecclesiology is the principle that the Catholic Church is at home everywhere where God is worshiped rightly and where the right doctrine is proclaimed (the two meanings of the word Orthodoxy). The idea that the Church Herself could be in diaspora in the West suggests that the Church is limited to particular territory and out of place in the West. This conception denies the Ecumenical (i.e. universal) nature of the Church, which in turn leads to abandon Her fundamental missionary ethos.

The concept of an "Orthodox Diaspora" allows for no room for Western converts, indeed, it does not allow for an Orthodox West! "[Speaking of a diaspora Orthodoxy] implies asserting the centrality of the mother churches and reducing the practice of Orthodoxy in the West to the condition of a periphery, which contradicts Orthodoxy's claim for universality ${ }^{17}$."

The canonical principle according to which one specific territory must only be under the jurisdiction of a single bishop is violated in the West, since - for understandable pastoral reasons each Mother Church has sent Her own bishops to take care of Her own priests and communities abroad. Since many years, there is much discussion concerning the appropriate way to go beyond the present situation characterized by the fact that the Orthodox people living in the same city belong to the jurisdiction of several bishops, according to their respective ethnicity. Ethnicity is for most Orthodox believer the de facto criterion deciding to which jurisdiction they belong.

${ }^{17}$ Maria Hämmerli, op. cit., p. 16. 
Maria Hämmerli is pessimist concerning the attempts to create a tighter collaboration between different foreign-based jurisdictions in a given Western country for four reasons: (1) First (1), there is an actual difference of language and national culture among the Orthodox migrants; Second (2), Orthodox ecclesiastical authorities in the West have a strong dependence on their Mother Churches that send them; Third (3), the historical relation between Orthodox Faith and ethnicity in the home countries of the Orthodox migrants is strong; this reinforces the importance of ethnic difference over the fact of having a common religion for Orthodox living in Western countries; Fourth (4), the migrations have not stopped and the continuous arrival of new migrants that do not speak the language of their new host countries leads communities that have started to inculturate in the West back to the language and cultural habits of their homelands, reinforcing the differences among the Orthodox jurisdictions and creating tensions and division within single jurisdictions ${ }^{18}$. For all those reasons, it is very unlikely that the attempts we see in France, Germany, Switzerland, and elsewhere to establish a "committee" or "gathering" of Orthodox bishops from different jurisdictions will lead to a solution that would allow the canonical principal of a single bishop for a single territory to be restored.

\section{The Restauration of the Missionary Ethos of the Church}

The missionary ethos of the Church is a consequence of the fact that the ultimate goal in human life is theosis, the union with God. God desires all men to be in union with Himself: this is the ground for His move towards us, which was accomplished through the incarnation of Jesus Christ, who became man in order the open the path for us to be able to become gods by partaking in His divine energies. God's love for mankind is the source and ground of

${ }^{18}$ The case of the Sourozh diocese in UK is very telling in this regards. See Maria Hämmerli and Edmnund Mucha, "Innovation in the Russian Orthodox Church: The Crisis in the Diocese of Sourozh in Britain," in M. Hämmerli and J.-F. Mayer, op. cit., pp. 291-302. 
mission. The goal of mission is to bring back mankind in its right relationship with its Creator.

"The Orthodox understanding of the incarnation does have a feature that was unique to missionary thinking in the earliest period of the church: the Orthodox maintained that each race, each culture, each identifiable group had the right to receive the gospel in tis own language ${ }^{19}$." The incarnation is a translation, Christ becomes near (Emmanuel), in order for mankind to understand and receive the Gospel. For this reason Jesus spoke Aramaic, the language of His compatriots and the Gospels were written in Greek, the common international language of the time.

James J. Stamoolis argues ${ }^{20}$ that the Church did Her missionary work according to three principles ${ }^{21}$. First (1), the vernacular language should be used in worship. Each Orthodox should be able to worship God in his own language. This idea is rooted in the event of Pentecost, where the message of the Gospel is given in many languages. Second (2), as soon as worthy men are ready, indigenous clergy should be ordained. Three (3), local churches that self-govern themselves should be established, when the time comes.

This whole process is parallel to Christ's incarnation: as the Word of God was made flesh in a specific culture, the Gospel has to be preached using the words of each specific community and to be incarnated in each specific culture.

Two risks, opposed to each other are manifest for Orthodox living in the West. On the one hand (1), the experiences of the last decades in the West show that the main risk in granting independence too early to local Orthodox communities lies in the

${ }^{19}$ James J. Stamoolis, "Eastern Orthodox Mission Theology," (pp. 59-63) in the International Bulleting of Missionary Research, 1984, p. 59.

${ }^{20}$ See James J. Stamoolis, Easter Orthodox Mission Theology Today, Orbis and Life and Light Publishers, 1986.

${ }^{21}$ Stamoolis draws these three principles from the example of Sts. Cyrille and Methodius, which were later followed by the Russian missions, especially in the $19^{\text {th }}$ century. 
lack of roots and strength of the new communities: they are prone to deform the substance of Holy Tradition by being influenced by the local dominant secular culture. They mistake the necessary of enculturation of the message of the Gospel with the dangerous idea that the Gospel itself must adapt to the moral and doctrinal elements of the culture it is preached to. In our case, this means concretely that local converts from Western Europe tend to accept that principles that have no traditional Christian basis reshape and redefine (especially) the moral content of Holy Tradition. On the other hand (2), the actual situation with multiple bishops having their jurisdiction on the same place does not respect the canons of the Church whose aim is to bring clarity and unity among the Christians living in one place by gathering them under a single bishop. This situation, based on the acceptation of the diaspora concept tends to perpetuate a situation where the spiritual center is elsewhere and where an authentic enculturation of Orthodoxy is not possible.

The idea that the Gospel needs to be enculturated implies that it has to be expressed to a specific people in its own language, using its own cultural codes. However, the enculturation of the Gospel does not mean that the culture that receives the Gospel should shape the doctrinal or moral content of the Gospel itself. Enculturation the translation of the apostolic message in the communication means available in a specific culture - is rather the point of departure from which this culture can be transformed and transfigured from within by the Gospel in order to become an Orthodox culture, the culture of a baptized nation.

For an independent local church to be established, two conditions seems necessary to me: (1) that the majority of the Orthodox of a given country are from indigenous origin, which gives a basis for a local Orthodox culture ${ }^{22}$ and the necessary resources to establish local bishops; (2) that the majority of local converts (and their children) be uncompromising with Western secular culture on

${ }^{22}$ For example a French Orthodox culture, as there is a Romanian Orthodox culture. 
the moral level and forcefully maintain the exclusive character of Christian truth, refusing to adapt and translate Orthodoxy within the language and norms of Pluralism. The Gospel has to be translated into French and German, not to be adapted to the dominant culture of todays France and Germany.

Only the restoration of the missionary ethos of the Church may fulfill these two conditions. (1) The restoration of the missionary ethos of the Church will lead to more converts and to a progressive and natural enculturation of the Gospel; (2) the missionary ethos of the Church, remaining grounded in a strong belief in the exclusive character of Christian truth will avoid this enculturation process to become an excuse to compromise the Gospel by contaminating it with ideas and moral principles coming from the dominant secular and postmodern culture of the West.

The restoration of the missionary ethos is a return to the Great Commission:

All power is given unto me in heaven and in earth. Go ye therefore, and teach all nations, baptizing them in the name of the Father, and of the Son, and of the Holy Ghost: Teaching them to observe all things whatsoever I have commanded you: and, lo, I am with you always, even unto the end of the world. Amen (Matthew 28.19-20).

Those words, given by the Lord to the Apostles, are the foundation of the missionary ethos of the Church. All Orthodox Christians are called to take part in the mission of the Church, since all are members of the Church. "As the Father has sent me, I am sending you" (Jn 20:21). We are sent to baptize all nations in the name of the Holy Trinity and to teach all nations to observe Jesus' commandments. Not only individual persons will be baptized, but also whole nations. Western nations have to be brought back to their initial baptism, which took place many centuries ago. Saint Paul, the Apostle of the Nations, said, "Necessity is laid upon me; yea woe is 
unto me, if I preach not the gospel!" (1 Cor 9:16). He showed by his example and word the way of a truly incarnated missionary ethos:

For though I be free from all men, yet have I made myself servant unto all, that I might gain the more. And unto the Jews I became as a Jew, that I might gain the Jews; to them that are under the law, as under the law, that I might gain them that are under the law; to them that are without law, as without law, (being not without law to God, but under the law to Christ,) that I might gain them that are without law. To the weak became I as weak, that I might gain the weak: I am made all things to all men, that I might by all means save some (1 Cor 9:19-22).

The heart of the missionary ethos of the Church is humility and love for others - to become as similar and close as possible to those we are witnessing to. However, the heart of authentic mission necessitates maintaining Christian doctrine and practice without any shame before the secular and postmodern culture. Only he that both love his neighbors and loves Truth without fearing Prescriptive Pluralism can fully embrace the mission of the Church in the West. 